\title{
Enhancement of high temperature PEMFC stability using catalysts based on Pt supported on SiC based materials.
}

\author{
Justo Lobato*, Hector Zamora, Jorge Plaza, Pablo Cañizares, and Manuel A. \\ Rodrigo \\ University of Castilla-La Mancha, Chemical Engineering Department, Enrique Costa \\ Novella Building, Av. Camilo José Cela, 12.13071 Ciudad Real, Spain. \\ * Corresponding author: Phone: +34 926295300 Ext. 6350. Fax: +34 926295256. \\ Email: Justo.Lobato@uclm.es
}

\begin{abstract}
With the aim of overcome the carbon supports of high temperature Proton Exchange Membrane Fuel cells (HT-PEMFC) electrodes, two novel non-carbonaceous support based on $\mathrm{SiC}$ have been assessed, $\mathrm{SiC}$ and $\mathrm{SiCTiC} .40 \%$ wt. Pt was successfully deposited on them and they were physicochemical and electrochemically characterized. Both catalysts on $\mathrm{SiC}$ based materials showed a very high electrochemical stability in the half cell experiments in comparison with Pt on carbon support, showing a lower degradation rate of the electrochemical surface area (ECSA). Membrane Electrode Assemblies (MEAs) were prepared with the different catalysts and tested in a single cell $\left(25 \mathrm{~cm}^{2}\right)$ operated at $160{ }^{\circ} \mathrm{C}$. The $\mathrm{Pt} / \mathrm{SiCTiC}$ showed a good performance and the highest stability in the fuel cell tests carried under the same operation conditions.
\end{abstract}

Keywords: Platinum; HT-PEMFC; Catalyst Support; Carbides; Durability 


\section{Introduction}

Solutions for clean and sustainable energy is becoming a critical issue for the future of our Planet. There is a progressive depletion of fossil fuels, and at the same time an increasing concentration of greenhouse gases in the atmosphere. Climate change damages can be watched on TV news. The use of more sustainable energy sources can mitigate the negative effects of using the current fossil fuel technologies. In this scenario fuel cells have receive recently great attention because of its low emissions of harmful greenhouse gases such as $\mathrm{CO}_{2}, \mathrm{NO}_{\mathrm{x}}, \mathrm{SO}_{2}$, etc and hence have generated a lot of interest among the scientific community [1].

Proton Exchange Membrane Fuel Cell (PEMFCs) technology is approaching to the commercialization but two main drawbacks must be overcome in order to reach the FC technology to the society. These are the high cost and the low durability of the systems. With respect to both, PEMFC electrocatalysts have been identified as the main responsible. Thus, nowadays there is an enormous interest for searching low cost, high performance and durability catalysts for PEMFCs and two different approaches exist. The first approach is to reduce the catalyst usage through increasing platinum utilization in the catalyst layers. This can be achieved by alloying Pt with inexpensive metals such as $\mathrm{Co}, \mathrm{Fe}$, etc and/or by utilizing unique support materials for Pt nano particles deposition. The other approach is to develop non-precious metal-based electrocatalysts materials [2] It is well known that supported metal catalysts show improved stability and higher activity compared to unsupported bulk metal catalysts. Surface area, porosity, electrical conductivity, electrochemical stability and surface functional groups characterise a support [3]. It is also well known that the conventional used carbon support materials are susceptible to oxidation under the chemical and electrochemical conditions at both electrodes in the fuel cell [3-5]. Thus, new materials based on advanced carbonaceous 
and non-carbonaceous materials (oxides, carbides...) are object of research. An interesting overview about them can be found elsewhere [3]. Especially, Si and Ti based oxides, carbides or borides have focused much attention in the last years to be used as electrocatalyst supports for fuel cell applications, achieving promising results in terms of durability and performance [6-9]

Our group has been working in phosphoric acid doped Polybenzimidazole (PBI) based high temperature PEMFCs (HT-PEMFCs) since 2004 because of the several advantages of working at high temperatures $\left(100-200{ }^{\circ} \mathrm{C}\right)$ such as water management and heat removal are not a problem. This technology operates above $100{ }^{\circ} \mathrm{C}$. Therefore, water is in vapour phase at atmospheric pressure, and it can be easily removed from the system. In addition, temperature gradient between the fuel cell and environment is larger. This means that heat removal is easier, and it becomes an advantage with respect to Low temperature PEMFC [10-12]. Although, this technology could be considered a mature one, the same problems with respect to the low temperature PEMFC exists.

Thus, in this work, two novel non carbonaceous catalyst supports ( $\mathrm{SiC}$ and a composite one, $\mathrm{SiCTiC}$ ) for electrodes in high temperature PEMFC running with phosphoric acid doped PBI membranes have been prepared, characterized and applied in a single cell. Different authors have tested previously SiC based materials $[5,13]$ for electrodes in low temperature PEMFC or Nafion- based PEMFC but never for PBI based HTPEMFCs as authors knowledge. Only one previous work by our group shows preliminary results with $\mathrm{SiC}$ but in the microporous layer of the electrode for HTPEMFC but not as catalyst support [14].

\section{Experimental Procedure}

\subsection{Catalyst synthesis}


The both non carbonaceous catalyst supports ( $\mathrm{SiC}$ and the composite $\mathrm{SiCTiC})$ used in this work were provided by SICAT Company (Paris, France). These materials were used as received. The composite one presents a Ti content of $13.89 \% \mathrm{wt}$. ( $\mathrm{SiC}: \mathrm{TiC}=$ 90:10 \% molar approx.).

The catalyst synthesis procedure consists of the deposition of platinum from a precursor salt (chloroplatinic acid hexa-hydrate, Sigma-Aldrich). To prepare a batch of $1 \mathrm{~g}$ of catalyst, $600 \mathrm{mg}$ of support ( $\mathrm{SiC}, \mathrm{SiCTiC}$ or Vulcan for comparison purposes) was added to a $500 \mathrm{~mL}$ of $0.1 \mathrm{M}$ formic acid solution (98\%, Panreac) kept thermostatic at $80{ }^{\circ} \mathrm{C}$. Then, $21.2 \mathrm{~mL}$ of a $50 \mathrm{mg} / \mathrm{L}$ chloroplatinic acid hexa-hydrate solution was added very slowly, and the mixture was kept under agitation at $80{ }^{\circ} \mathrm{C}$ for one hour. Then, the suspension was left to cool at room temperature and the solid filtered and dried, weighed and characterized. The target concentration of platinum in the catalyst was $40 \%$ wt.

\subsection{Physicochemical characterization}

X-Ray Diffraction (XRD) analyses were performed on a Philips PW-1700 diffractometer with rotating anode applying $\mathrm{K} \alpha$ corresponding to the transition from copper radiation for different samples.

To study the electrochemical behavior of the different produced catalysts, a voltammetric study was carried out using the different electrodes manufactured with these catalysts. The electrodes consisted of commercial carbon cloth with a Micro Porous Layer (MPL) deposited (Freudenberg Vliesstoffe, H23C2) and a catalyst layer deposited onto it with the catalyst to be tested. The voltammetric tests consisted of 400 cycles $(-0.2-+1.0 \mathrm{~V}$ vs. $\mathrm{Ag} / \mathrm{AgCl})$ at $50 \mathrm{mV} / \mathrm{s}$, in a medium consisting of $2.0 \mathrm{M}$ phosphoric acid solution at $50{ }^{\circ} \mathrm{C}$ with a gold counter-electrode. Before each test, 
gaseous nitrogen was bubbled for 20 minutes in order to render the electrolyte inert in order to remove the $\mathrm{O}_{2}$ of the electrolyte. Luggin capillary tube was used to connect reference electrode to the half-cell. More details about the set up can be found elsewhere [15]. After that, degradation of tested catalysts was studied by the variation of ElectroChemical Surface Area (ECSA) values of them. The technique for determining the ECSA of fuel cell electrodes by CV analysis has been used for several decades. The procedure involves cycling the electrode of interest over a voltage range where charge transfer reactions are adsorption-limited at the activation sites. ECSA values were obtained by the $\mathrm{H}_{2}$ desorption peak area, by the equation 1 [16].

$$
E C S A=\frac{A_{P t}}{v \cdot C} \cdot \frac{1}{L_{e}}
$$

Where $A_{P t}$ is the peak area $\left(\mathrm{A} . \mathrm{V} / \mathrm{cm}^{2}\right), v$ is the scan rate $(\mathrm{V} / \mathrm{s}), C$ is the charge required to reduce the proton monolayer of the active platinum $\left(0.21 \mathrm{mC} / \mathrm{cm}^{2}\right)$, and $L e$ is the platinum load in the catalyst layer $\left(0.3 \mathrm{mg} / \mathrm{cm}^{2}\right)$.

Transmission Electron Microscopy (TEM) analyses were performed on a Jeol JEM 2100 TEM operating at $200 \mathrm{kV}$ with an Orius (2x2 MPi) Gatan Digital Camera. Specimens were prepared by dispersing the samples in acetone and depositing a drop onto a C-coated $\mathrm{Cu}$ grid. TEM images were analyzed using Digital Micrograph software from Gatan.

\subsection{MEA manufacture}

A catalyst layer was deposited by spraying the catalyst ink over the commercial electrodes (Freudenberg Vliesstoffe, H23C2). The catalyst ink for the cathode electrodes consisted of a commercial 40\% wt. Pt/C (Fuel Cell Store), or $40 \%$ wt. Pt/SiC 
or $40 \%$ wt. Pt/SiCTiC catalyst, PBI ionomer (1.5 wt. \% PBI in N,N-dimethylacetamide, DMAc, 1-20 PBI/support ratio), and DMAc as a dispersing solvent. This Pt amount on the catalyst powder was fixed according to the optimization results of the catalyst layer for HT-PEMFCs achieved in previous results performed by our research group [17] and it is in agreement with the ratios used in other works shown in the literature [18]. For the anode, the commercial catalyst, $\mathrm{Pt} / \mathrm{C}$, was used. In all cases, the Pt loading on the two electrodes (anode and cathode) was $0.6 \mathrm{mg} \mathrm{Pt} / \mathrm{cm}^{2}$. After the deposition of the catalyst layer, the electrodes were dried at $190{ }^{\circ} \mathrm{C}$ for $2 \mathrm{~h}$, with the purpose of removing traces of DMAc. The electrodes were then wetted with a solution of $10 \%$ PA.

Electrodes were left to absorb the acid for one day. For the preparation of the MEA, a PBI membrane was doped in 85 wt. \% PA for 5 days, in order to achieve good proton conductivity. The doping level acquired by the membrane was 9 molecules approx. of acid per polymer repeating unit. The corresponding thickness of the membrane was $83.2 \mu \mathrm{m}$. The superficial acid on the membrane was thoroughly wiped off with filter paper and the membrane was used to prepare the MEA. In order to fabricate the MEA, the doped membrane was sandwiched between a couple of electrodes and the whole system was hot-pressed at $130{ }^{\circ} \mathrm{C}$ and $1 \mathrm{MPa}$ for $15 \mathrm{~min}$. The completed MEA was inserted into the cell between bipolar plates of graphite (with a five serpentine channels frame in each plate). The geometrical area of each electrode was $25 \mathrm{~cm}^{2}$.

\subsection{Fuel cell characterization procedure}

MEAs prepared with thermal cured PBI membranes were mounted and characterized in a commercially available Cell Compression Unit (CCU) provided by Baltic fuel cells $\mathrm{GmbH}$ (Germany). The break-in procedure consists of operation at $0.1 \mathrm{~A} / \mathrm{cm}^{2}$ and $\lambda\left(\mathrm{H}_{2}\right.$ / air ratio) of 1.5/2 for 48 hours. A preliminary stability test was conducted by 
increasing the current density to $0.2 \mathrm{~A} / \mathrm{cm}^{2}\left(160^{\circ} \mathrm{C}\right)$ and working at constant stoichmetric coefficients $\left(\lambda_{\mathrm{H} 2}\right.$ of 1.5 and $\lambda_{\text {air }}$ of 2$)$. For further characterization, a protocol test was carried out every $48 \mathrm{~h}$ since the final of the break-in procedure as reported elsewhere[14]. This protocol test consists of the following routine:

- Galvanostatic polarization curves. They were performed from the OCV to $0.4 \mathrm{~V}$. First with air at constant $\lambda_{\mathrm{H} 2 / \text { air }}=1.5 / 2$ and then with oxygen at constant $\lambda_{\mathrm{H} 2 / \mathrm{O} 2}$ $=1.5 / 9.5$.

- Electrochemical impedance spectroscopy (EIS) tests. The EIS tests were performed at $0.10 \mathrm{~A} / \mathrm{cm}^{2}$ with $10 \mathrm{mV} \mathrm{AC} \mathrm{perturbation} \mathrm{amplitude} \mathrm{and} \mathrm{frequency}$ range from $100 \mathrm{kHz}$ to $100 \mathrm{MHz}$. This sequence of EIS tests was carried out with air as oxidant and then the same procedure was repeated with oxygen.

- Cyclic voltammetries (CV). The Electrochemical surface area (ECSA) of cathode was estimated with this technique. The cathode side was purged with nitrogen and hydrogen flowed through anode side with flows of $0.1 / 0.1 \mathrm{~L} / \mathrm{min}$ $\mathrm{N}_{2} / \mathrm{H}_{2}$. The $\mathrm{CV}$ was carried out from $0.05 \mathrm{~V}$ to $1.0 \mathrm{~V}$ with a scan rate of 100 $\mathrm{mV} / \mathrm{s}$.

- Linear sweep voltammetry (LSV). This technique was performed to find out any crossover of gas flow through MEA. The same gases of the CV were fed with flows of $0.3 / 0.3 \mathrm{~L} / \mathrm{min} \mathrm{N}_{2} / \mathrm{H}_{2}$.

Thus, it could be considered this preliminary life test under accelerate stress conditions.

\section{Results and Discussion}

\subsection{Preparation of the catalysts}


Figure 1 shows the XRD of the two $\mathrm{SiC}$ based supports studied in this work. The main diffraction peaks at $2 \theta$ values of $35.541 .3^{\circ}, 60^{\circ}$, and $71.7^{\circ}$ approx. which correspond to (111), (200), (311) and (222) planes respectively and confirm the presence of $\beta$-SiC (cubic structure). For TiC, the main characteristic diffraction peaks are at $2 \theta$ values of $35.9^{\circ}(111)$ plane, $41.7^{\circ}(200)$ plane, $60.45^{\circ}(220)$ plane, $72.4^{\circ}(311)$ plane, and $76.1^{\circ}$ (222) plane. These peaks correspond to the fcc cubic structure. As it can be observed, both materials show similar diffraction peaks [18]. However, the main diffraction peak for $\mathrm{SiC}$ is at $35.5^{\circ}$ and for $\mathrm{TiC}$ is at $41.7^{\circ}$ which would explain the higher intensity of this peak in the SiCTiC sample.

\section{Figure 1}

On the other hand, figure 2 shows the XRD patterns of the different catalysts prepared in this work, and for comparison purposes, the commercial catalyst (Pt/Vulcan) is also shown. First of all, it can be said that the platinum catalyst was deposited successfully on the different support because the main peaks of the platinum crystals can be appreciated. Thus, peaks at $2 \theta$ values of $39.6^{\circ}, 46.1^{\circ}, 67.4^{\circ}$ which corresponding to $\mathrm{Pt}$ (111), Pt (200) and Pt (220) planes, respectively are observed in both samples. The platinum peaks are assigned according to the International Centre for Diffraction Data PDF 00-004-0802 and show a face-centered-cubic crystal structure for platinum. No phase changes or formation of oxides were observed for $\mathrm{TiC}$ or $\mathrm{SiC}$, indicating that the SiCTiC composite support remains stable during the catalyst deposition process. Moreover, a double type of peak is observed for $\mathrm{Pt}(111)$ plane $\left(39.6^{\circ}\right)$ which is most likely due to the $\mathrm{SiC}(200)$ plane $\left(41.3^{\circ}\right)$. For this reason, the average platinum crystallite size was calculated from Pt (200) plane using the Scherrer formula. This Pt (200) plane is used very often to calculate the crystallite size of Pt based catalysts [19, 
20]. Table 1 shows the Pt crystallite size on the two supports. Thus, the Pt crystallite size was $14.5 \%$ higher when $\mathrm{SiC}$ was used as support than when $\mathrm{SiCTiC}$ was used as support. On the other hand, the Pt crystallite size is higher when the $\mathrm{SiC}$ based supports were used than when Vulcan carbon support was used. This could be explained according to the different Brunauer-Emmett-Teller (BET) surface area of the supports. (BET values also shown on Table 1). The Vulcan carbon support has the highest value, around $250 \mathrm{~m}^{2} / \mathrm{g}$ whereas the $\mathrm{SiC}$ shows the lowest value, around $35 \mathrm{~m}^{2} / \mathrm{g}$.

\section{FIGURE 2}

\section{TABLE 1}

Figure 3 shows the distribution of the platinum particles (obtained from TEM analyses. TEM images can be observed in the supplemental material) of the different catalysts prepared under the same operation conditions and for comparison purposes the commercial one is also shown. As Figure 3 shows, no significant differences in the particle size distribution can be observed between the lab-made and the commercial catalyst with the Vulcan carbon support, indicating that the procedure applied in manufacturing is robust and that the particle size distribution strongly depends on the

support. However, comparing the effect of the support on the particle size shows a clear influence because the difference between the catalysts based on Vulcan carbon and binary carbide is significant. The catalysts with carbonaceous supports show the smallest particle sizes. The higher BET surface of the carbonaceous materials compared with that of the binary carbide may favor the dispersion of the catalyst particles and prevent agglomeration during the manufacture of the catalyst. Initially, this result indicates that the active surface of the catalyst is expected to be higher in the case of the 
catalyst with the carbonaceous support material because of the lower size of the catalyst particles and the more efficient distribution associated with this lower size. It can be said that these results are in agreement with those obtained from the XRD analyses. Although, the platinum particle sizes average values are lower than those obtained by XRD. Thus, the Pt particles deposited on the $\mathrm{SiC}$ and $\mathrm{SiCTiC}$ had a size of 7.0 and 7.1 $\mathrm{nm}$, respectively, whereas the size of the commercial Pt particles deposited on the Vulcan carbon was around $3.5 \mathrm{~nm}$. These large Pt particle size values achieved for SiCbased catalyst are similar that achieved by other authors [6] and they were explained in terms of the characteristics of the substrate in a previous work [21].

\section{FIGURE 3}

There are various methods for the determination of the surface area of nanoparticle $\mathrm{Pt}$ electrodes such as TEM, XRD, gas-phase methods or electrochemical methods [22]. Assuming that Pt particles are spherical, the specific surface area of $\mathrm{Pt}\left(\mathrm{A}_{\mathrm{sp}}\right.$ in $\left.\mathrm{m}^{2} / \mathrm{g}_{\mathrm{Pt}}\right)$ particles can be calculated by using the equation 2 .

$$
A_{s p}=\frac{6000}{d \rho}
$$

where $\mathrm{d}$ is the particle size (in $\mathrm{nm}$ ) and $\rho$ is the Pt density. It is assumed that the bulk density of the Pt is $21.45 \mathrm{~g} / \mathrm{cm}^{3}$ [23]. The obtained results are shown in Table 1 . The particle size was calculated from the TEM images (shown in the supplemental file). The obtained value for the case of Pt on Vulcan (commercial catalyst) is similar to other showed in literature because of the similar particle size, whereas for the case of $\mathrm{Pt}$ deposited on $\mathrm{SiC}$, our value is almost the half than the one obtained by Venkateswara et al. [23]. This was due because our Pt particle size $(7 \mathrm{~nm})$ is double than the one obtained by them $(3.5 \mathrm{~nm})$. Although, it must be pointed out that, the Pt loading in their 
case was around $20 \%$ wt., which is the half than ours (40\% wt.) which would explain the different particle size, and hence the different $\mathrm{A}_{\mathrm{sp}}$ reached.

\subsection{Electrochemical characterization of the catalysts}

To study the electrochemical behavior of the different produced catalysts, a voltammetric study was carried out on the different electrodes manufactured with these catalysts. Figure 4a shows the voltammograms of various cycles, which compare the performances of the different catalysts prepared, containing the same platinum concentration (nominal content: $40 \%$ wt.) and Pt loading $\left(0.3 \mathrm{mg} \mathrm{Pt} / \mathrm{cm}^{2}\right)$ but different supports.

In the high voltage region (0.6-1 V vs. $\mathrm{Ag} / \mathrm{AgCl}$ electrode), it appears an increasing of the current, associated with the Platinum oxides formation [24]. This slope decreases in all cases during the experiment, due to the platinum deactivation processes, formation of platinum oxide layers that decrease the activity of the catalyst and migration of the platinum particles to the electrolyte, decreasing the intensity of this region. This fact could be observed also in the platinum reduction region, which appears at $0.7 \mathrm{~V}$ vs. $\mathrm{Ag} / \mathrm{AgCl}$. It must be remarked that a decreasing of the intensity in the highest voltage region $(0.9-1 \mathrm{~V}$ vs $\mathrm{Ag} / \mathrm{AgCL}$ electrode) appears in the case on non-carbonaceous catalyst, due to the formation of $\mathrm{Si}$ and $\mathrm{Ti}$ oxides passivate layers, which present lower electrical conductivity, decreasing the maximum current peak achieved. Double layer does not suffer several changes in the non-carbonaceous materials, which means that these materials do not present important structural or chemical changes during the experiments. On the other hand, the commercial Vulcan catalysts (homemade and commercial one) exhibited a lower decreasing of the double layer region $(0.2-0.4 \mathrm{~V})$, 
which means a slightly decreasing of the surface area. This could be related with the degradation of the carbonaceous support, due to the oxidation of the support decreases the porosity and related with this fact, the surface area of the material $[25,26]$. In all cases, the hydrogen absortion/desorption peaks appear at same potential region, located between $-0.2 / 0.15 \mathrm{~V}$ vs $\mathrm{Ag} / \mathrm{AgCl}$ electrode. The BET surface area of the materials has a clear effect to the double layer contribution of the voltammetries. It can be observed that $\mathrm{Pt} /$ Vulcan carbon $\left(184 \mathrm{~m}^{2} / \mathrm{g}\right.$ BET area) catalyst exhibits the best contribution to the double layer, while $\mathrm{Pt} / \mathrm{SiCTiC}\left(55 \mathrm{~m}^{2} / \mathrm{g}\right)$ and $\mathrm{Pt} / \mathrm{SiC}\left(18 \mathrm{~m}^{2} / \mathrm{g}\right)$ present a lower contribution to double layer effect, especially in the voltage region located between 0.1 and $0.3 \mathrm{~V}$ vs $\mathrm{Ag} / \mathrm{AgCl}$. In addition, these BET area values are lower than $\mathrm{BET}$ areas of supports. The surface area decreasing percentage is directly related with the Pt loading on the catalysts (around 40\% in the case of non-carbonaceous materials, obtaining BET decreasing of $44 \%$ and $42 \%$ for $\mathrm{SiCTiC}$ and $\mathrm{SiC}$, respectively and $34.5 \%$ in the case of commercial catalyst), which asseverates the successfully Pt deposition in all cases. Respect to the orientation of the platinum particles, it can be observed that in the case of those supported on the $\mathrm{SiC}$ is divided between $\left(\begin{array}{lll}1 & 0 & 0\end{array}\right)$ and $\left(\begin{array}{lll}1 & 1 & 1\end{array}\right)$ faces $[27,28]$, attending to the presence of two $\mathrm{H}_{2}$ desorption peaks. In the case of Pt deposited on $\mathrm{SiCTiC}$, the division of the crystalline plane orientation is less evident, with a preferent orientation to the $\left(\begin{array}{lll}1 & 0 & 0\end{array}\right)$ face. In the case of the commercial catalyst, $\mathrm{Pt} / \mathrm{C},\left(\begin{array}{lll}1 & 0 & 0\end{array}\right)$ orientation is the most observed, presenting only one hydrogen desorption peak. Using the area of these absortion/desorption peaks, ECSA values were calculated for each catalyst for cycles 1 and 400, using the equation 1, in order to analyze the evolution of the active area of the catalyst during the experiment. The obtained values are shown in Table 2 where the degradation of the catalysts in terms of the variation of ECSA is also shown. 
It can be observed that non-carbonaceous catalysts exhibit higher ECSA values than commercial catalyst, but the platinum particles are also higher in $\mathrm{SiC}$ and $\mathrm{SiCTiC}$ catalysts. The higher double layer contribution effect in the case of Vulcan carbon catalyst could mask part of the $\mathrm{H}_{2}$ absorption/desorption peak, reducing the active area observed. This fact is also observed in the case of the homemade $\mathrm{Pt} / \mathrm{C}$, but in this case, the observable ECSA presents the highest values, which suggests that the synthesis method improves the active area of the homemade $\mathrm{Pt} / \mathrm{C}$ catalyst compared with the commercial one. It also remarkable that $\mathrm{SiC}$ and $\mathrm{SiCTiC}$ catalyst exhibit the lowest ECSA degradation, which could be attributed to the higher electrochemical stability of non-carbonaceous materials compared with Vulcan carbon $[14,26]$. In addition, the higher size of the platinum particles observed in the case of non-carbonaceous catalyst could improve the electrochemical resistance of the catalyst, avoiding the agglomeration and migration catalyst processes. In comparing the ECSA decreases of the commercial and the homemade $40 \%$ wt. Pt/C catalysts, it can be seen a slightly lower ECSA degradation in the homemade catalyst, which also presented a slightly higher Pt particle size distribution in the TEM measurements.

\section{FIGURE 4}

\section{Table 2}

\subsection{Tests in a single HT-PEMFC}

Figure 5 shows the cell voltage versus time of MEAs prepared with the different catalysts (commercial $\mathrm{Pt} / \mathrm{C}, \mathrm{Pt} / \mathrm{SiC}$ and $\mathrm{Pt} / \mathrm{SiCTiC}$ ) studied in this work. The negative values correspond with the break-in period, approximately $60 \mathrm{~h}$. This was carried out at $120^{\circ} \mathrm{C}$ and $0.1 \mathrm{~A} / \mathrm{cm}^{2}$. It can be clear observed that the MEA prepared with the $\mathrm{Pt} / \mathrm{SiC}$ 
showed a strange behaviour. At that temperature, $120^{\circ} \mathrm{C}$, the performance was very low and then it was decided to increase the temperature up to $160{ }^{\circ} \mathrm{C}$ to increase the performance. In the case of SiCTiC-based catalyst and standard Vulcan catalyst MEAs, temperature was changed just before to perform the first characterization test, at the end of the break in process, keeping at $160{ }^{\circ} \mathrm{C}$ and $0.2 \mathrm{~A} / \mathrm{cm}^{2}$ during all the 100 hours of steady state time.

The stability is one of the most consideration for the actual application and commercialization of PEMFCs, and the stability and durability of electrocatalyst is an important factor limiting the life service of this technology. Thus, it was decided perform a study during $100 \mathrm{~h}$. Although, it is not a long period, it can be considered long enough to evaluate the stability of new materials, above all, considering that at time 0,48 and $96 \mathrm{~h}$ different electrochemical characterization tests (polarization curves with oxygen and air; impedance spectroscopy, linear sweep voltammetries, and cyclic voltametries) were carried out. These techniques contribute to accelerate the degradation of the MEA [29].

As far the authors know, there are no single cell results from PBI-based HT- PEMFC systems where $\mathrm{Pt} / \mathrm{SiC}$ or $\mathrm{Pt} / \mathrm{SiCTiC}$ are shown. Thus, it is impossible to compare with literature. But, all the experiments were carried out in the same cell and under the same operation conditions which allow us to compare them. From Figure 5, it can be observed that the MEA prepared with $\mathrm{Pt} / \mathrm{SiC}$ performed in a strange way. This MEA reached the lowest performance and it seems that it did not reach the steady state conditions. Due to the low voltage, after 30 hours at steady state conditions, oxygen was fed to the cathode side instead of air, with a stoichiometric coefficient of $\lambda_{\mathrm{O} 2}=9.5$, in order to evaluate if the observed problems were caused by mass transfer limitations on the cathode side. It can be observed that when oxygen was fed, the voltage started to 
increase until the second characterization test. After that, the voltage remained stable until the end of the experiment. On the other hand, if we pay attention to the last 48 hours of operation where, the three MEAs performed in a perfect way, the degradation rate can be calculated. Thus, the MEA prepared with $\mathrm{Pt} / \mathrm{SiCTiC}$ showed a degradation value of $0.191 \mathrm{mV} / \mathrm{h}$ approx. whereas the MEAs prepared with the commercial catalyst or with $\mathrm{Pt} / \mathrm{SiC}$ reached a value close to $0.450 \mathrm{mV} / \mathrm{h}$. If the total duration of the experiment is taken into account these values are $0.204 \mathrm{mV} / \mathrm{h}$ and $0.555 \mathrm{mV} / \mathrm{h}$ for the $\mathrm{Pt} / \mathrm{SiCTiC}$ and $\mathrm{Pt} / \mathrm{C}$, respectively. On the other hand, the best performance was achieved by the MEA prepared with the commercial catalyst and the lowest one by the MEA prepared with $\mathrm{Pt} / \mathrm{SiC}$.

\section{Figure 5}

Figure 6 shows the polarization curves that were carried out at the beginning and at the end of the experiment and with oxygen and air to the MEAs prepared with the three catalysts. Table 3 shows some parameters obtained from these polarization curves. It can be observed clearly how the MEA prepared with $\mathrm{Pt} / \mathrm{SiC}$ performed the worst and its performance is very low with air. While at the end of the experiment, the differences with the other MEAs when they were running with oxygen are low. On the other hand, it is also observed that the MEA prepared with $\mathrm{Pt} / \mathrm{SiCTiC}$ performed lower than the one with the commercial catalyst but the differences diminished at the end of the experiment in both cases, with air and oxygen. This was due to the higher stability of the catalyst supported on the $\mathrm{SiC}$ based materials as it was said above in the cyclic voltammetry study. Thus, the peak power density of the MEA with Pt/SiCTiC decreased a $17.2 \%$ with oxygen, and $20.0 \%$ with air, whereas in the case of the MEA with the commercial catalyst, the decrease was $23.7 \%$ and $32.6 \%$ with oxygen and air, respectively. 
Regarding the Open circuit voltage (OCV) values, it can be seen from Table 3 that there was little variation during the test, which means that not important mechanical failures of the phosphoric acid doped PBI membranes occurred. Thus, the main degradation effects must be due mainly to the degradation of the electrodes. Recently, it has been pointed out different degradation mechanisms that can occur in PBI based HT-PEMFCs regarding the catalyst layer degradation and can be found elsewhere [12]. Table 4 shows the ECSA values achieved from the cyclic voltammetries of each MEA tested. It can be observed that MEAs prepared with non-carbonaceous based catalyst on the cathode side exhibit a very low degradation (1.27 and $6.08 \%)$ as compared to the carbonaceous catalyst $(21.70 \%)$. The carbonaceous material showed the highest initial value of the ECSA. However, in the end of the experiment, the final ECSAs were the same for the three tested materials.

Thus, in order to get more information about the behaviours of these MEAs with Pt on new supports, impedance spectroscopy analyses were carried out at different times, $0 \mathrm{~h}$, $50 \mathrm{~h}$ and $100 \mathrm{~h}$.

\section{Figure 6}

\section{Tables 3 and 4}

Figures 7 and 8 show the different resistances obtained from the impedance spectroscopy analysis carried out with air and oxygen, respectively. Regarding the ohmic resistance ( $\mathrm{R}_{\mathrm{Ohm}}$ ), it can be said that it remained almost constant during the test, which means not high degradation of the PBI membrane occurred, which could contribute to a loos of conductivity like phosphoric acid loss [12]. With respect to the mass transfer resistance $\left(\mathrm{R}_{\mathrm{MT}}\right)$, it must be remarked that in the case of the tests running with oxygen, this resistance did not appear because of the high amount of oxygen available in the cell (see experimental section). The MEA with the $\mathrm{Pt} / \mathrm{SiC}$ shows the 
highest values and also the highest increase of the evolution of this parameter which can be related with the catalyst layer thickness and porosity. We must bear in mind that the GDL and the PBI are commercials, so the differences among the different MEAs are in the catalyst layers because of the use of catalyst with different supports and hence different properties. Although, $\mathrm{Pt} / \mathrm{SiC}$ has been studied recently in literature $[5,13]$, most of the results shown are in half cells and not fuel cell results in $\mathrm{H}_{2} / \mathrm{Air}$ or $\mathrm{O}_{2}$ PEMFC have been found by the authors to compare our results with. Finally, the charge transfer resistance $\left(\mathrm{R}_{\mathrm{ct}}\right)$ explains the best stability of the MEA with $\mathrm{Pt} / \mathrm{SiCTiC}$ and the lower performance with respect to the MEA with the commercial catalyst $\mathrm{Pt} / \mathrm{C}$, because of the lowest variation with time and the higher values of the $\mathrm{R}_{\mathrm{ct}}$, respectively.

The highest values of mass transfer and charge transfer resistances obtained by the MEA with $\mathrm{Pt} / \mathrm{SiC}$ could explain its lowest performance achieved but the polarization curves do not reflect the increase of these resistances when air is used as it can be seen in Table 3 where the same power density is reached at 50 and $100 \mathrm{~h}$.

In order to improve the performance of these non-carbonaceous based catalysts, different routes could be studied. An increasing of the $\mathrm{Pt} \%$ content on the catalyst reduces the thickness of the layer and the amount of support, which could reduce the problems related to the conductivity and increasing the performance of the system, keeping the stability of the layer. An improvement of the electrical conductivity of the raw material using dopping processes should reduce the resistivity of the material, increasing the voltage value of the MEA. Finally, using of bimetallic catalysts could improve the ECSA of the catalyst particles, increasing the performance of the system.

\section{Figure 7}

\section{Figure 8}


Finally, Figure 9 shows the evolution of the different LSV performed during the preliminary lifetest for each MEA.

\section{Figure 9}

As it can be observed, not noticeable changes are observed in the shape of the curves, which may mean that no appreciable crossover occurs over the tests, which suggests that the PBI membrane did not suffer important damages or degradation. This is in agreement with the high OCV values achieved in the different polarization curves during the characterization tests.

\section{Conclusions}

Catalysts based on Pt deposited in three different supports (Vulcan, $\mathrm{SiC}$ and $\mathrm{SiCTiC}$ ) have been studied.

The catalysts on the new support based on $\mathrm{SiC}$ materials have been prepared successfully and were characterized leading to higher Pt particle size.

The catalyst based on the new supports led to a high electrochemical stability in the halfcell studies.

For the first time, the $\mathrm{SiC}$ based catalyst supports were applied in a single cell operating at $160{ }^{\circ} \mathrm{C}$ and were compared with a MEA with the commercial catalyst $\mathrm{Pt} / \mathrm{C}$. The $\mathrm{Pt} / \mathrm{SiCTiC}$ showed the best stability and performed slight lower than the commercial catalyst. On the other hand, the large Pt particle size achieved in SiC-based catalysts increases the stability of the fuel cell, but also decreases the active area, reducing the performance of the system. This particular large particle size is provided by the surface properties of $\mathrm{SiC}$ based materials (low BET surface, with microporosity character) which are closely similar to the values and dispersion of the Pt particles achieved by other researchers. 
The commercial availability of these SiC-based materials and their excellent stability properties under the corrosion environmental work conditions of the HT-PEMFC situate this material as an alternative to the carbonaceous materials and further research is undergoing in order to increase the performance of these catalysts.

\section{Acknowledgements}

The authors further thank the European Commission as part of this work was supported by the Seventh Framework Programme through the project CISTEM (FCH-JU Grant Agreement Number 325262). SICAT Company is thanked for providing us gently the $\mathrm{SiC}$ and $\mathrm{SiCTiC}$ materials.

\section{Reference}

[1] L. Carrette, K.A. Friedrich, U. Stimming, Fuel Cells 1 (2001) 5-39.

[2] Z. Chen, D. Higgins, A. Yu, L. Zhang, J. Zhang, Energy \& Environmental Science 4 (2011) 3167-3192.

[3] S. Sharma, B.G. Pollet, Journal of Power Sources 208 (2012) 96-119.

[4] L.M. Roen, C.H. Paik, T.D. Jarvi, Electrochemical and Solid-State Letters 7 (2004) 19-22.

[5] R. Dhiman, E. Johnson, E.M. Skou, P. Morgen, S.M. Andersen, Journal of Materials Chemistry A 1 (2013) 6030-6036.

[6] S.N. Stamarin, J. Speder, R. Dhiman, M. Arenz, E.M. Skou, ACS Appl.Mater. Interfaces 7 (2015) 6153-6161

[7] S. Yin, S. Mu, H. Lv, N. Cheng, M. Pan, Z. Fu, Applied Catalysis B: Environmental 93 (2010) 233-240

[8] Y. C. Kimmel, L. Yang, T. G. Kelly, S. A. Rykov, J. G. Chen, Journal of Catalysis 312 (2014) 216-220

[9] D. J. You, X. Jin, J. H. Kim, S. Jin, S. Lee, K. H. Choi, W. J.Baek, C. Pak, J. M. Kim, International Journal of Hydrogen Energy 40 (2015) 12352 - 12361

[10] J. Lobato, P. Cañizares, M.A. Rodrigo, D. Úbeda, F.J. Pinar, Journal of Membrane Science 369 (2011) 105-111.

[11] Q. Li, J.O. Jensen, R.F. Savinell, N.J. Bjerrum, Progress in Polymer Science 34 (2009) 449-477.

[12] F.J. Pinar, P. Cañizares, M.A. Rodrigo, D. Úbeda, J. Lobato, Journal of Power Sources 274 (2015) 177-185.

[13] H. Lv, S. Mu, N. Cheng, M. Pan, Applied Catalysis B: Environmental 100 (2010) 190-196. 
[14] J. Lobato, H. Zamora, P. Cañizares, J. Plaza, M.A. Rodrigo, Journal of Power Sources 288 (2015) 288-295.

[15] J. Lobato, P. Cañizares, M.A. Rodrigo, J.J. Linares, Electrochimica Acta 52 (2007) 3910-3920.

[16] J. Lobato, P. Cañizares, M.A. Rodrigo, D. Úbeda, F.J. Pinar, J.J. Linares, Fuel Cells 10 (2010) 770-777.

[17] J. Lobato, P. Canizares, M.A. Rodrigo, J.J. Linares, D. Ubeda, F.J. Pinar, Fuel cells 10 (2010) 312-319

[18] A.S. Pushkarev, I.V. Pushkareva, S.A. Grigoriev, V.N. Kalinichenko, M.Yu. Presniakov, V.N. Fateev, , International Journal of Hydrogen Energy 40 (2015) 1449214497

[19] P. Nguyen, C. Pham, Applied Catalysis A: General 391 (2011) 443-454.

[20] J. Lobato, P. Cañizares, M.A. Rodrigo, J.J. Linares, Applied Catalysis B: Environmental 91 (2009) 269-274.

[21] J. Lobato, P. Cañizares, D. Ubeda, F.J. Pinar, M.A. Rodrigo, Applied Catalysis B: Environmental 106 (2011) 174-180.

[22] J. Lobato, H. Zamora, J. Plaza, M.A. Rodrigo, ChemCatChem 8 (2016) 848-854

[23] S. Trasatti, O.A. Petrii, Journal of Electroanalytical Chemistry 327 (1992) 353376.

[24] Ch. Venkateswara Rao, SK. Singh, B. Viswanathan, Indian Journal of Chemistry 47 (2008) 1619-1625.

[25] T. Reier, M. Oezaslan, P. Strasser. ACS Catal. 2 (2012) 1765-1772.

[26] H. Zamora, P. Cañizares , M.A, Rodrigo, J. Lobato, Fuel Cells 15(2) (2015) 375383.

[27] F. Büchi, N. Inaba, T.J. Schmidt, Polymer Electrolyte Fuel Cell Durability, Springer Science + Business Media 2009

[28] Q.He, X. Yang, W. Chen, S. Mukerjee, B. Koel, S. Chen, Phys. Chem. Chem. Phys. 12 (2010) 12544-12555.

[29] K. Kinoshita, J. Electrochem. Soc. 137 (2010) 845-848.

[30] G-B. Jung, K-Y. Chuang, T-C. Jao, C-C. Yeh, C-Y. Lin. Applied Energy. 100 (2012) 81-86. 


\section{Caption for Figures}

Figure 1. XRD patterns of the $\mathrm{SiC}$ and $\mathrm{SiCTiC}$ supports

Figure 2. XRD patterns of the catalyst based on Pt deposited on both $\mathrm{SiC}$ and $\mathrm{SiCTiC}$ supports

Figure 3. Distribution of platinum particle size for the different catalysts tested:

40\%Pt/SiC-TiC; $\boldsymbol{\Delta}$ lab-made 40\%Pt/Vulcan XC-72; commercial 40\%Pt/Vulcan XC$72 ; \bullet 40 \% \mathrm{Pt} / \mathrm{SiC}$

Figure 4. Ciclic voltammetries of the different catalysts. $2 \mathrm{M} \mathrm{H}_{3} \mathrm{PO}_{4}$ electrolyte, $\mathrm{T}=50$ ${ }^{\circ} \mathrm{C}$, scan rate $50 \mathrm{mV} / \mathrm{s}$. The potentials are shown versus $\mathrm{Ag} / \mathrm{AgCl}$ reference electrode. $\mathrm{A}$ ) $\mathrm{Pt} / \mathrm{SiC}$; B) Pt/SiCTiC and C) Pt/C, commercial.

Figure 5. Evolution of cell voltage with time of MEAs with different catalysts. $T=160$ ${ }^{\circ} \mathrm{C}$; current density $0.2 \mathrm{~A} / \mathrm{cm}^{2}$. Break in period: $60 \mathrm{~h}$ at $120^{\circ} \mathrm{C}$ and at $0.1 \mathrm{~A} / \mathrm{cm}^{2}$. Blue line $=$ Commercial catalysts $(\mathrm{Pt} / \mathrm{C})$; Red line $=\mathrm{Pt} / \mathrm{SiCTiC}$; Purple line $=\mathrm{Pt} / \mathrm{SiC} ;$ Black lines indicate the timer when different characterization techniques were carried out.

Figure 6. Polarization curves carried out at the beginning and at the end with both oxygen and air to the three MEAs $\left(25 \mathrm{~cm}^{2}\right)$ studied in this work at $160{ }^{\circ} \mathrm{C}$. A) Polarization curves at $\mathrm{t}=0 \mathrm{~h}$ and with air. B) Polarization curves at $\mathrm{t}=0 \mathrm{~h}$ and with oxygen. C) Polarization curves at $\mathrm{t}=100 \mathrm{~h}$ and with air $\mathrm{d}$ ) Polarization curves at $\mathrm{t}=100 \mathrm{~h}$ and with oxygen

Figure 7. Different resistance obtained from the Impedance Spectroscopy analysis carried out at different times to the MEAs with the three catalysts running with air. $\mathrm{j}=0.1$ $\mathrm{A} / \mathrm{cm}^{2}$. a) Ohmic Resistance; b) Charge transfer Resistance; c) Mass transfer Resistance 
Figure 8. Different resistance obtained from the Impedance Spectroscopy analysis carried out at different times to the MEAs with the three catalysts running with oxygen. $\mathrm{j}=0.1 \mathrm{~A} / \mathrm{cm}^{2}$ a) Ohmic Resistance; b) Charge transfer Resistance;

Figure 9. Evolution of the LSV for the different MEAs tested during the lifetest. A) Vulcan XC72; B) SiCTiC; and C) SiC based MEAs 
Table 1. Pt content, Pt crystallite sizes obtained from XRD analyses, BET values of the supports and Specific surface area of Pt particles.

\begin{tabular}{ccccc}
\hline Catalyst & $\begin{array}{c}\text { Pt Content } \\
(\mathbf{\%})\end{array}$ & $\begin{array}{c}\text { Scherrer formula } \\
\text { (XRD) }\end{array}$ & $\begin{array}{c}\text { BET } \\
\left(\mathbf{m}^{2} / \mathbf{g}\right)\end{array}$ & $\begin{array}{c}\text { Specific } \\
\text { surface area* } \\
\left(\mathbf{m}^{2} / \mathbf{g}\right)\end{array}$ \\
\hline$P t / \mathrm{SiC}$ & $38.6 \pm 1.0$ & $8.7 \mathrm{~nm}$ & 35.3 & 40.0 \\
$P t / \mathrm{SiCTiC}$ & $39.1 \pm 1.1$ & $7.6 \mathrm{~nm}$ & 99.8 & 39.4 \\
$P t /$ Vulcan $\mathrm{XC}-72$ & $36.1 \pm 0.5$ & $4.2 \mathrm{~nm}$ & 258.4 & 79.9 \\
$($ commercial) & & & \\
* Calculated from TEM measurements (Tem images shown in the supplemental file) &
\end{tabular}


Table2. ECSA values at different cycles for all catalyst tested.

\begin{tabular}{cccc}
\hline Catalyst & $\begin{array}{c}\text { ECSA (Cycle 1) } \\
\left(\mathbf{m}^{\mathbf{2}} \mathbf{~}^{-\mathbf{1}}\right)\end{array}$ & $\begin{array}{c}\text { ECSA (Cycle 400) } \\
\left(\mathbf{m}^{\mathbf{2}} \mathbf{g}^{-\mathbf{1}}\right)\end{array}$ & $\begin{array}{c}\text { ECSA } \\
\text { degradation }(\%)\end{array}$ \\
\hline $40 \% \mathrm{Pt} / \mathrm{SiC}$ & 7.89 & 6.33 & 19.77 \\
$40 \% \mathrm{Pt} / \mathrm{SiCTiC}$ & 6.70 & 5.56 & 17.01 \\
$\begin{array}{c}\text { Commercial } \\
(40 \% \mathrm{Pt} / \mathrm{C})\end{array}$ & 6.58 & 4.58 & 31.09 \\
$\begin{array}{c}\text { Homemade }(40 \% \\
\mathrm{Pt} / \mathrm{C})\end{array}$ & 8.60 & 6.04 & 29.82 \\
\hline
\end{tabular}


Table 3. Values of OCV and Peak power density at different times, obtained from the polarization curves at $160{ }^{\circ} \mathrm{C}$ with oxygen and air.

\begin{tabular}{|c|c|c|c|c|c|c|c|c|c|c|c|c|}
\hline \multirow[t]{2}{*}{ Catalyst } & \multicolumn{3}{|c|}{$\begin{array}{c}\mathrm{OCV}\left(\mathrm{O}_{2}\right) \\
(\mathrm{mV})\end{array}$} & \multicolumn{3}{|c|}{$\begin{array}{c}\text { OCV (Air) } \\
\text { (mV) }\end{array}$} & \multicolumn{3}{|c|}{$\begin{array}{c}\text { Peak Power } \\
\left(\mathrm{O}_{2}\right)\left(\mathrm{mW} / \mathrm{cm}^{2}\right)\end{array}$} & \multicolumn{3}{|c|}{$\begin{array}{c}\text { Peak Power } \\
(\text { Air })\left(\mathrm{mW} / \mathrm{cm}^{2}\right)\end{array}$} \\
\hline & $0 \mathrm{~h}$ & $50 \mathrm{~h}$ & $100 \mathrm{~h}$ & $0 \mathrm{~h}$ & $50 \mathrm{~h}$ & $100 \mathrm{~h}$ & $0 \mathrm{~h}$ & $50 \mathrm{~h}$ & $100 \mathrm{~h}$ & $0 \mathrm{~h}$ & $50 \mathrm{~h}$ & $100 \mathrm{~h}$ \\
\hline $\mathrm{Pt} / \mathrm{SiC}$ & 960 & 980 & 996 & 870 & 895 & 932 & 90.1 & 217.0 & 215.7 & 44.32 & 70.8 & 71.1 \\
\hline Pt/SiCTiC & 930 & 940 & 940 & 830 & 840 & 840 & 227.4 & 196.7 & 188.2 & 130 & 105.6 & 104.0 \\
\hline $\begin{array}{c}\text { Commercial } \\
(\mathrm{Pt} / \mathrm{C})\end{array}$ & 940 & 940 & 900 & 850 & 840 & 820 & 353.6 & 321.6 & 269.9 & 208.9 & 160.4 & 140.8 \\
\hline
\end{tabular}


Table 4. Evolution of ECSA obtained from $\mathrm{H}_{2}$ desorption peak of cyclic voltammetries performed during the different protocol tests.

\begin{tabular}{ccccc}
\hline $\begin{array}{c}\text { Cathode } \\
\text { catalyst }\end{array}$ & $\begin{array}{c}\text { ECSA 1 } \\
\left(\mathrm{m}^{2} / \mathrm{g} \mathrm{Pt}\right)\end{array}$ & $\begin{array}{c}\text { ECSA 2 } \\
\left(\mathrm{m}^{2} / \mathrm{g} \mathrm{Pt}\right)\end{array}$ & $\begin{array}{c}\text { Final ECSA } \\
\left(\mathrm{m}^{2} / \mathrm{g} \mathrm{Pt}\right)\end{array}$ & Total degradation (\%) \\
$\begin{array}{c}\mathrm{Pt} / \text { Vulcan } \\
\mathrm{XC72}\end{array}$ & 17.05 & 14.69 & 13.36 & $\mathbf{2 1 . 7 0}$ \\
$\mathrm{Pt} / \mathrm{SiC}$ & 13.37 & 13.29 & 13.20 & $\mathbf{1 . 2 7}$ \\
$\mathrm{Pt} / \mathrm{SiCTiC}$ & 13.82 & 13.35 & 12.98 & $\mathbf{6 . 0 8}$ \\
\hline
\end{tabular}




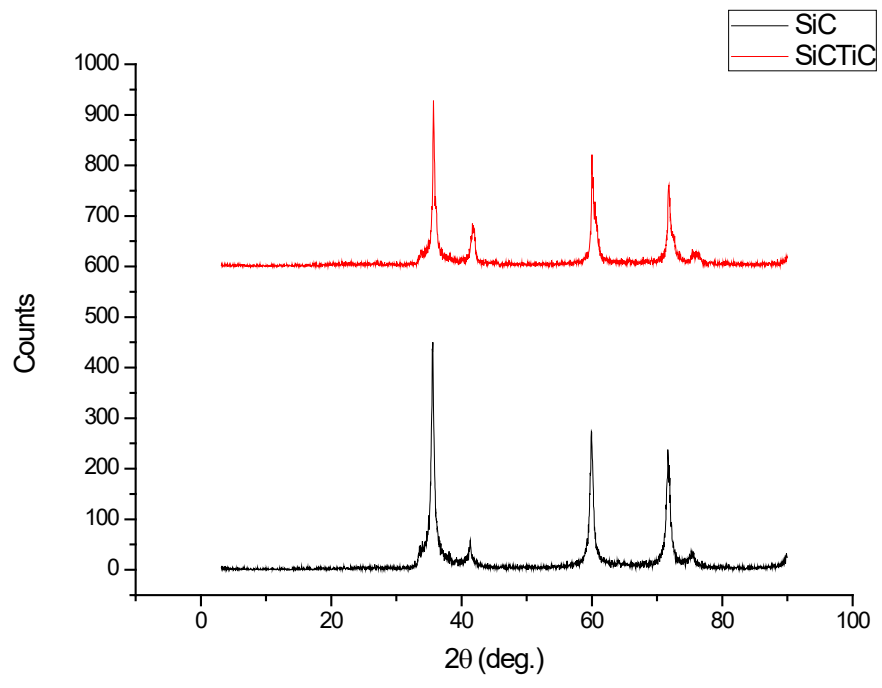

FIGURE 1. XRD patterns of the SiC based supports 


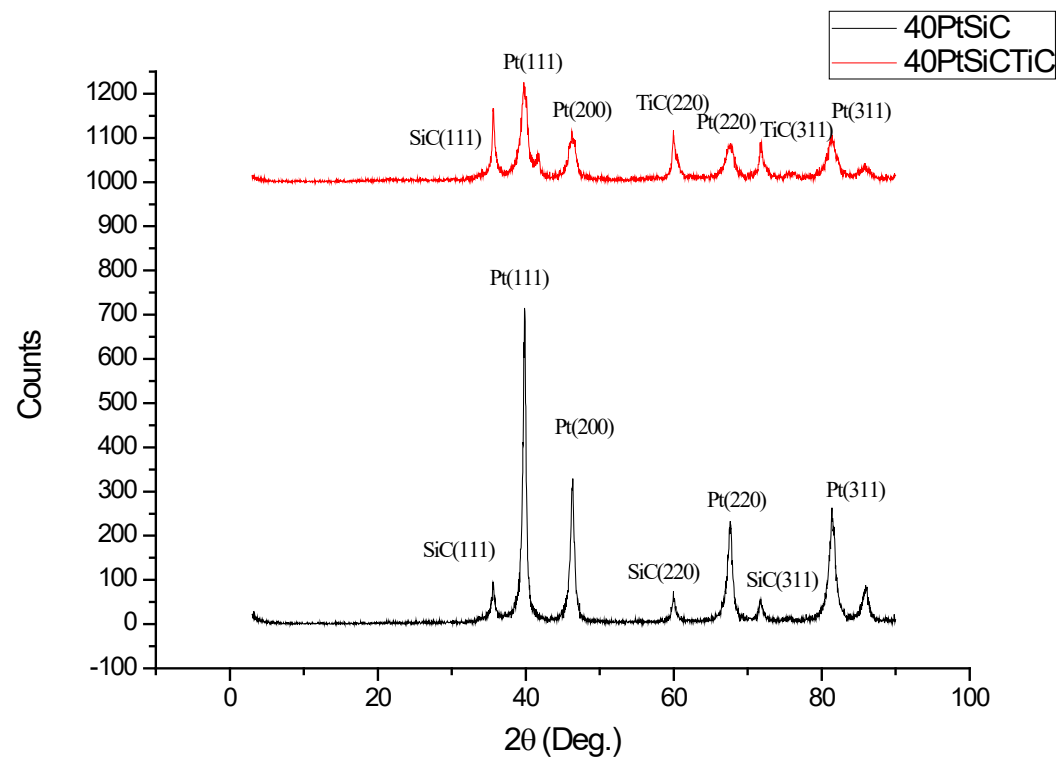

Figure 2. XRD patterns of the catalyst based on Pt deposited on both $\mathrm{SiC}$ and $\mathrm{SiCTiC}$ supports 


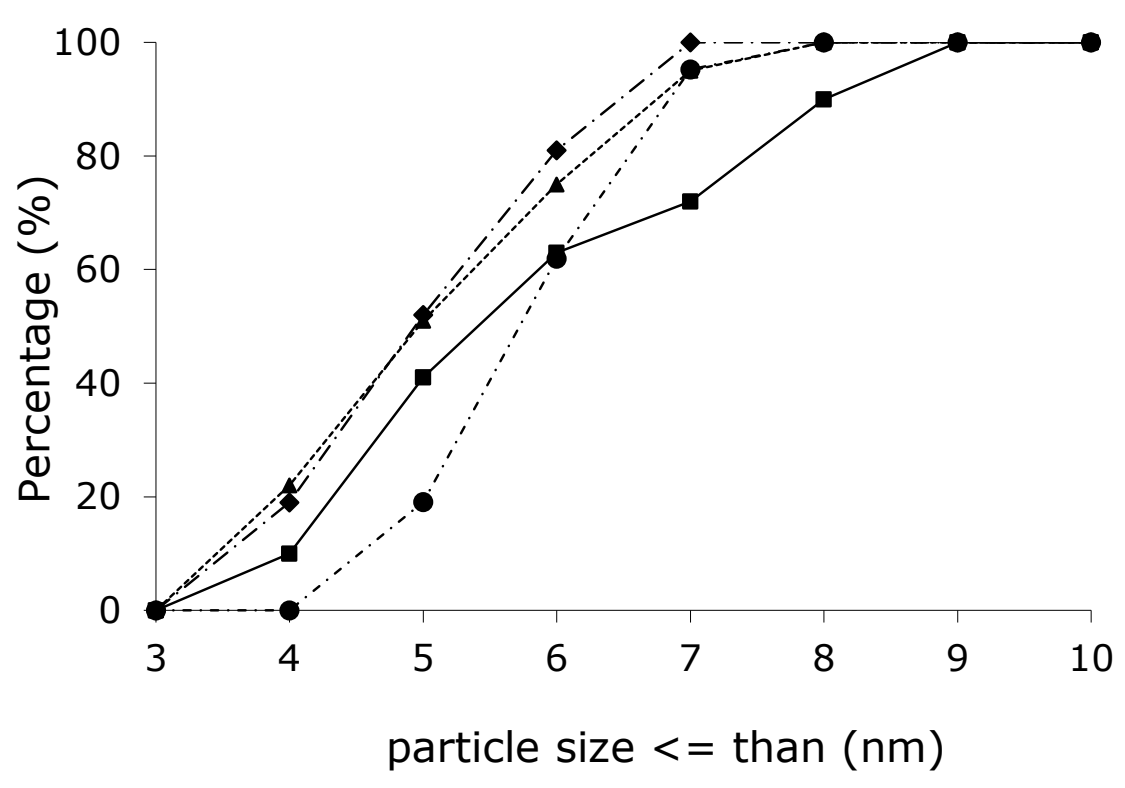

Figure 3. Distribution of platinum particle size for the different catalysts tested: $40 \%$ wt. Pt/SiC-TiC; $\boldsymbol{\Delta}$ lab-made 40\% wt. Pt/Vulcan XC-72; commercial 40\% wt. $\mathrm{Pt} /$ Vulcan XC-72; • 40\% wt. Pt/SiC 

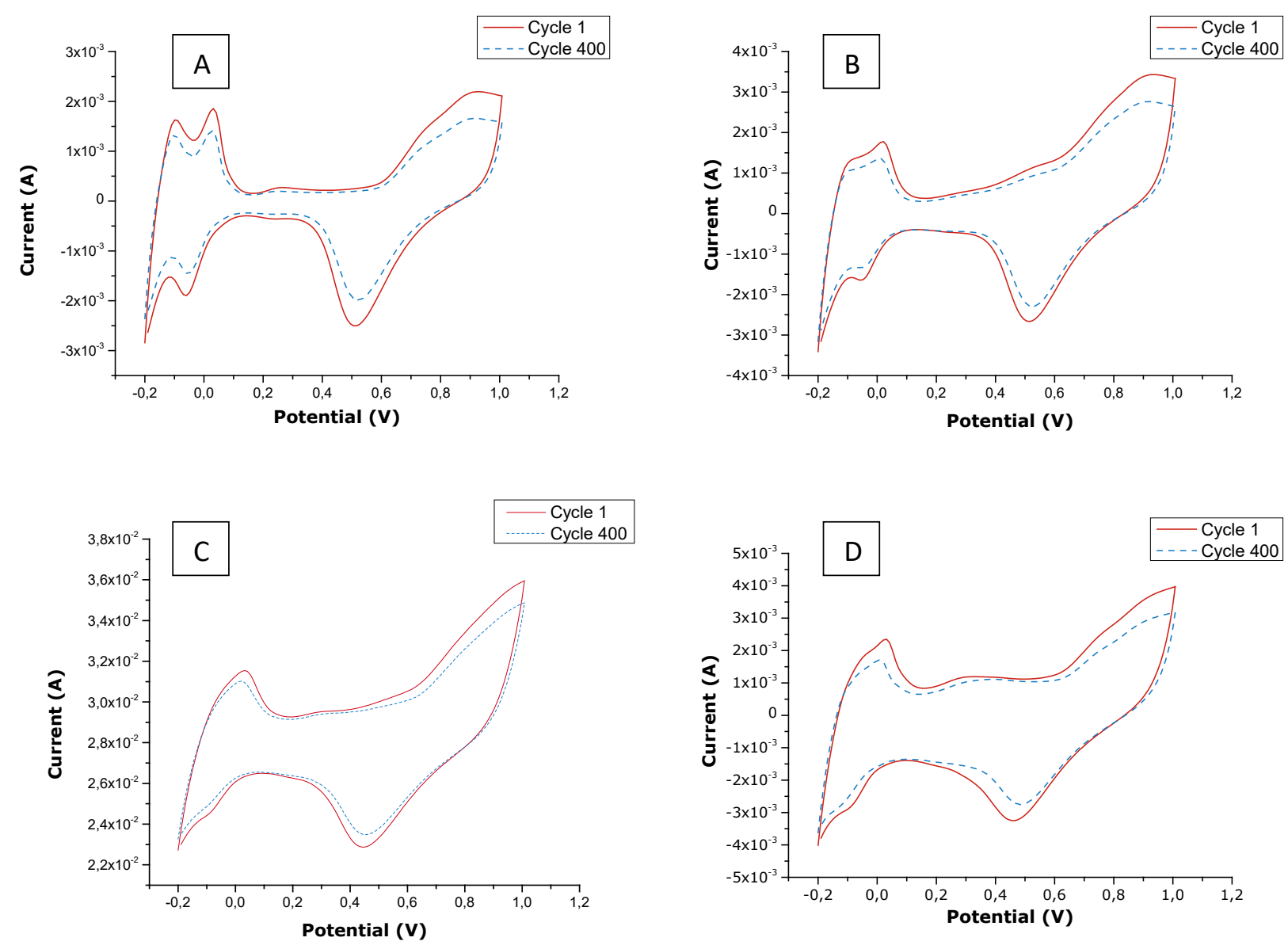

Figure 4. Cycle 1 and 400 voltammograms of different catalyst tested: 4A) 40\% wt. $\mathrm{Pt} / \mathrm{SiC}$; 4B) 40\% wt. Pt/SiCTiC; 4C) Commercial catalyst, Pt/C; 4D) Homemade 40\% wt. Pt/C 


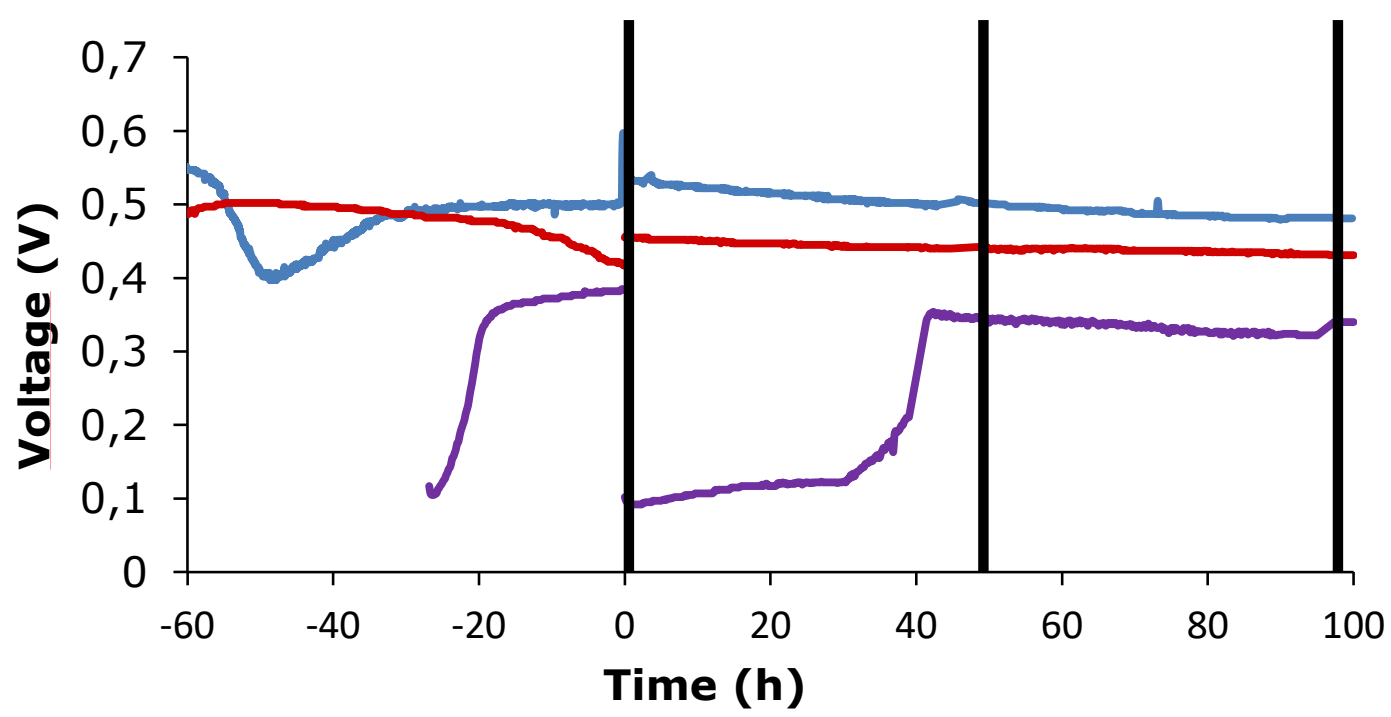

FIGURE 5. Evolution of cell voltage with time of MEAs with different catalysts. $T=$ $160{ }^{\circ} \mathrm{C}$; current density $0.2 \mathrm{~A} / \mathrm{cm}^{2}$. Break in period: $60 \mathrm{~h}$ at $120^{\circ} \mathrm{C}$ and at $0.1 \mathrm{~A} / \mathrm{cm}^{2}$. Blue line $=$ Commercial catalysts $(\mathrm{Pt} / \mathrm{C}) ;$ Red line $=\mathrm{Pt} / \mathrm{SiCTiC} ;$ Purple line $=\mathrm{Pt} / \mathrm{SiC}$; Black lines indicate the timer when different characterization techniques were carried out. 

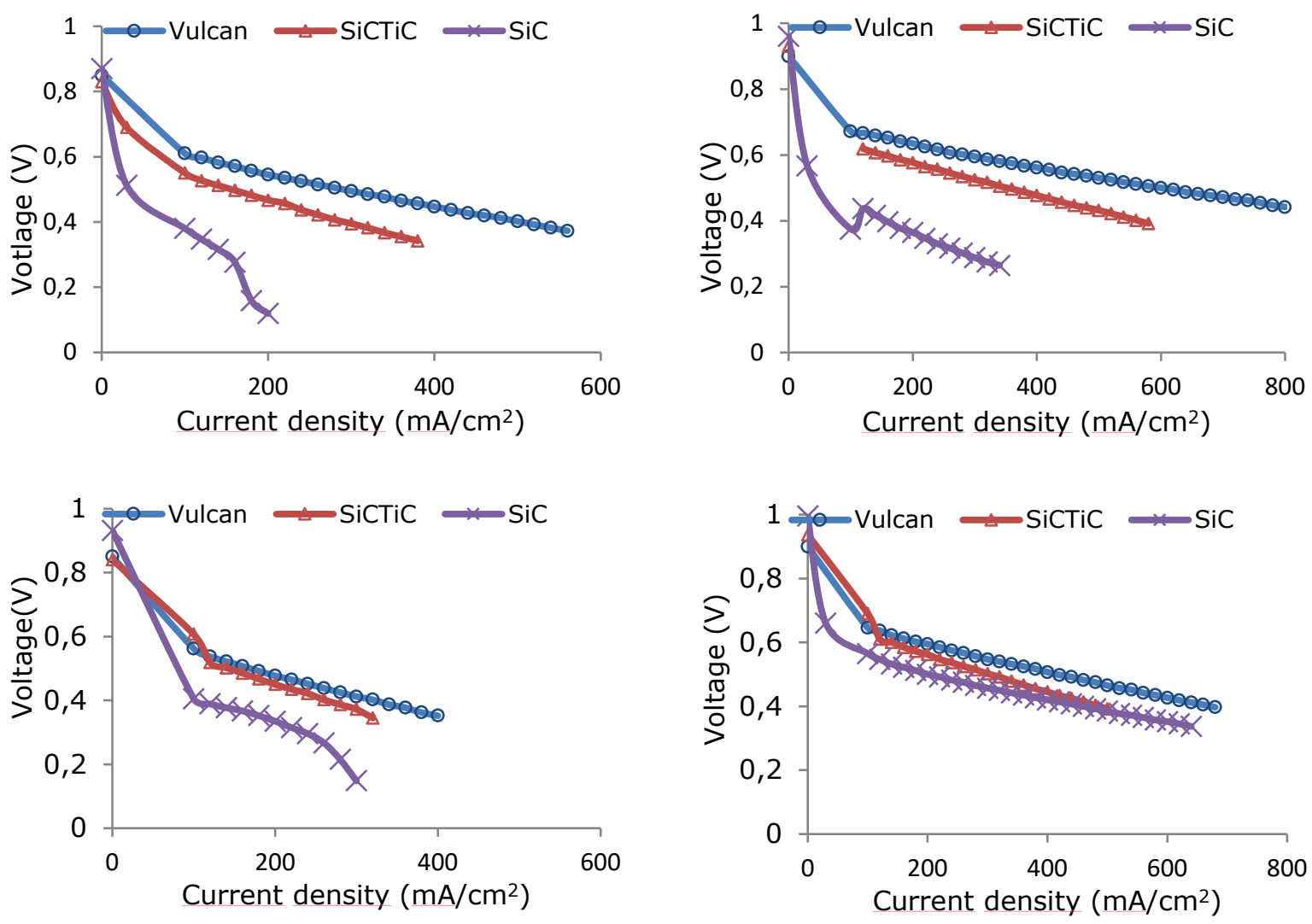

Figure 6. Polarization curves carried out at the beginning and at the end with both oxygen and air to the three MEAs $\left(25 \mathrm{~cm}^{2}\right)$ studied in this work at $160^{\circ} \mathrm{C}$. A) Polarization curves at $\mathrm{t}=0 \mathrm{~h}$ and with air. B) Polarization curves at $\mathrm{t}=0 \mathrm{~h}$ and with oxygen. C) Polarization curves at $\mathrm{t}=100 \mathrm{~h}$ and with air $\mathrm{d}$ ) Polarization curves at $\mathrm{t}=100 \mathrm{~h}$ and with oxygen. 


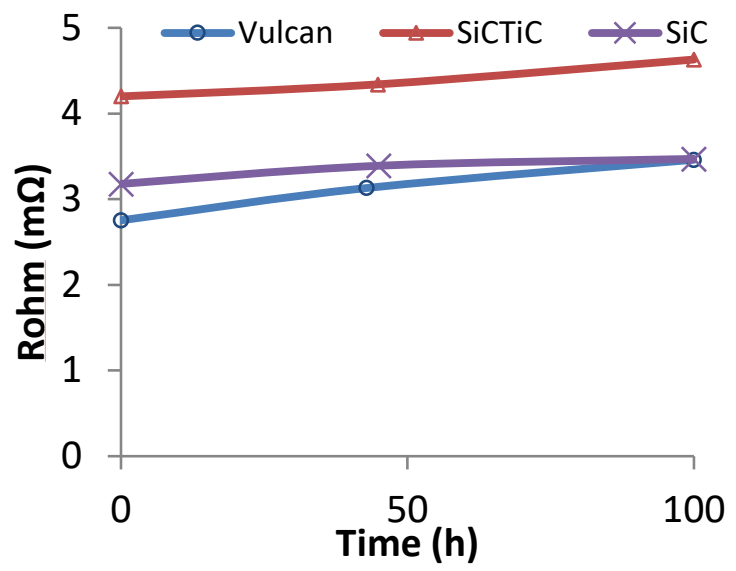

(a)

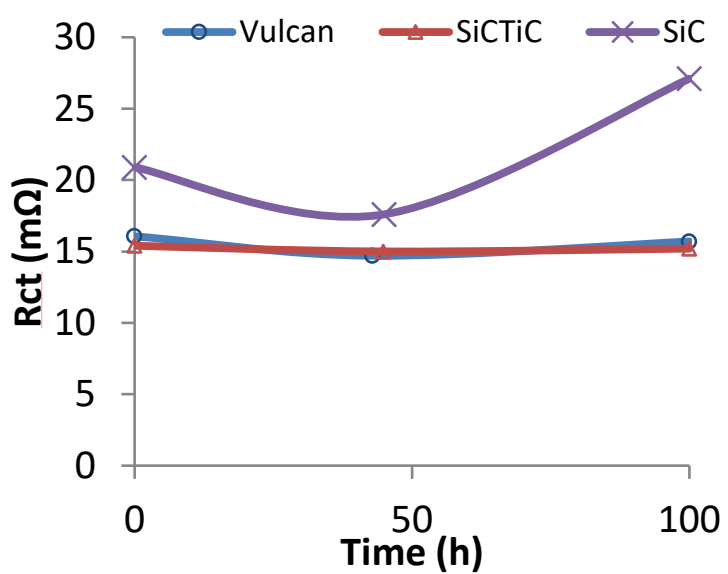

(b)

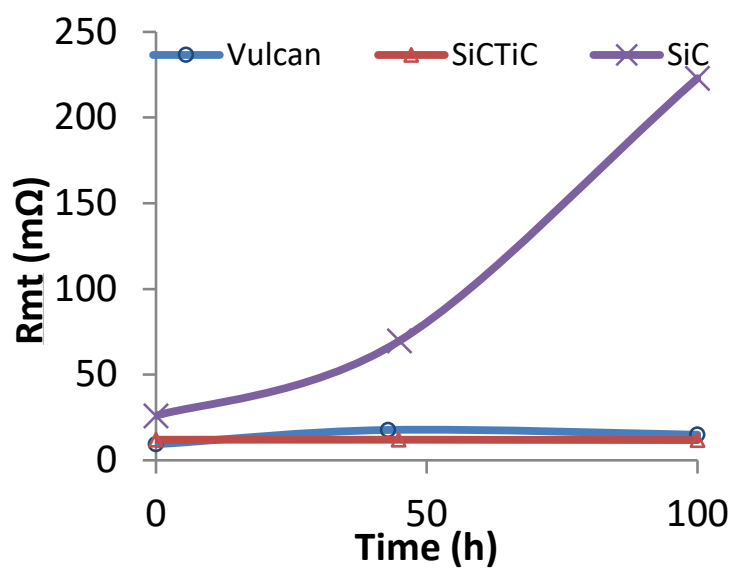

(c)

Figure 7. Different resistance obtained from the Impedance Spectroscopy analysis carried out at different times to the MEAs with the three catalysts running with air. $\mathrm{j}=$ $0.1 \mathrm{~A} / \mathrm{cm}^{2}$. a) Ohmic Resistance; b) Charge transfer Resistance; c) Mass transfer Resistance 


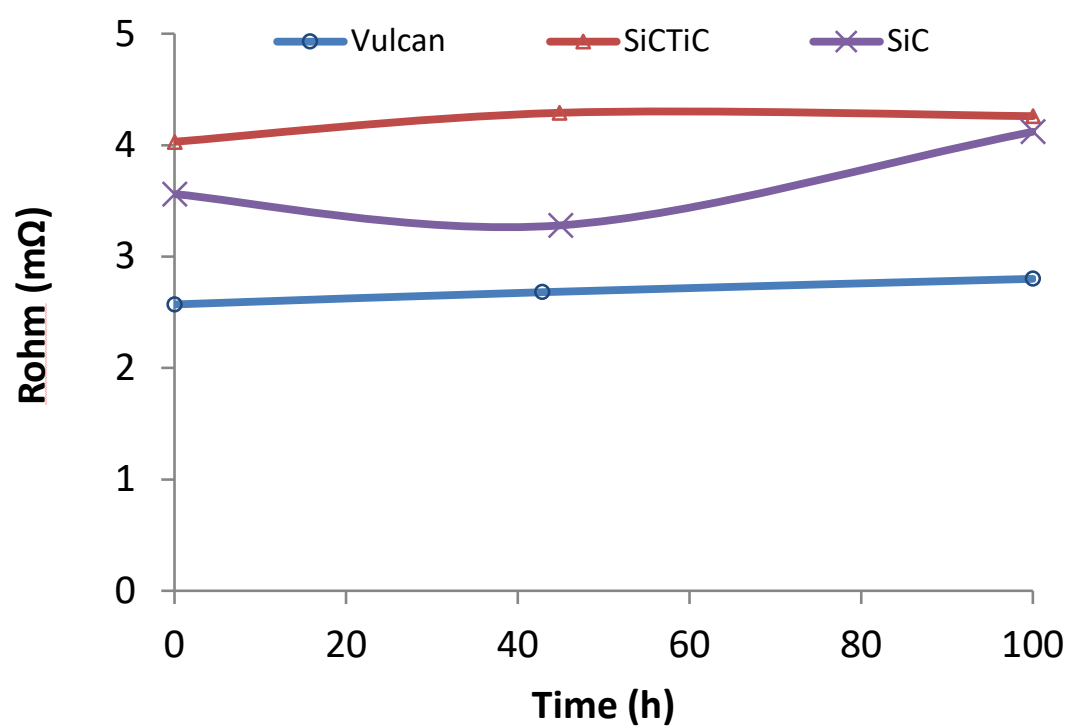

(a)

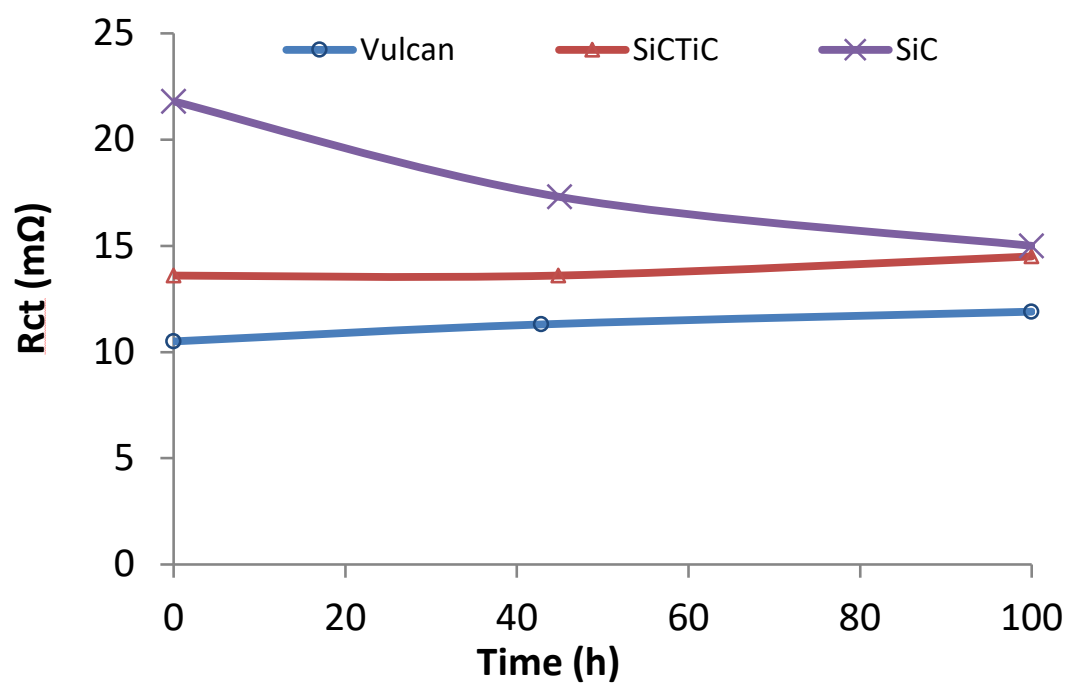

(b)

Figure 8. Different resistance obtained from the Impedance Spectroscopy analysis carried out at different times to the MEAs with the three catalysts running with oxygen, $\mathrm{j}=0.1 \mathrm{~A} / \mathrm{cm}^{2}$. a) Ohmic Resistance; b) Charge transfer Resistance 

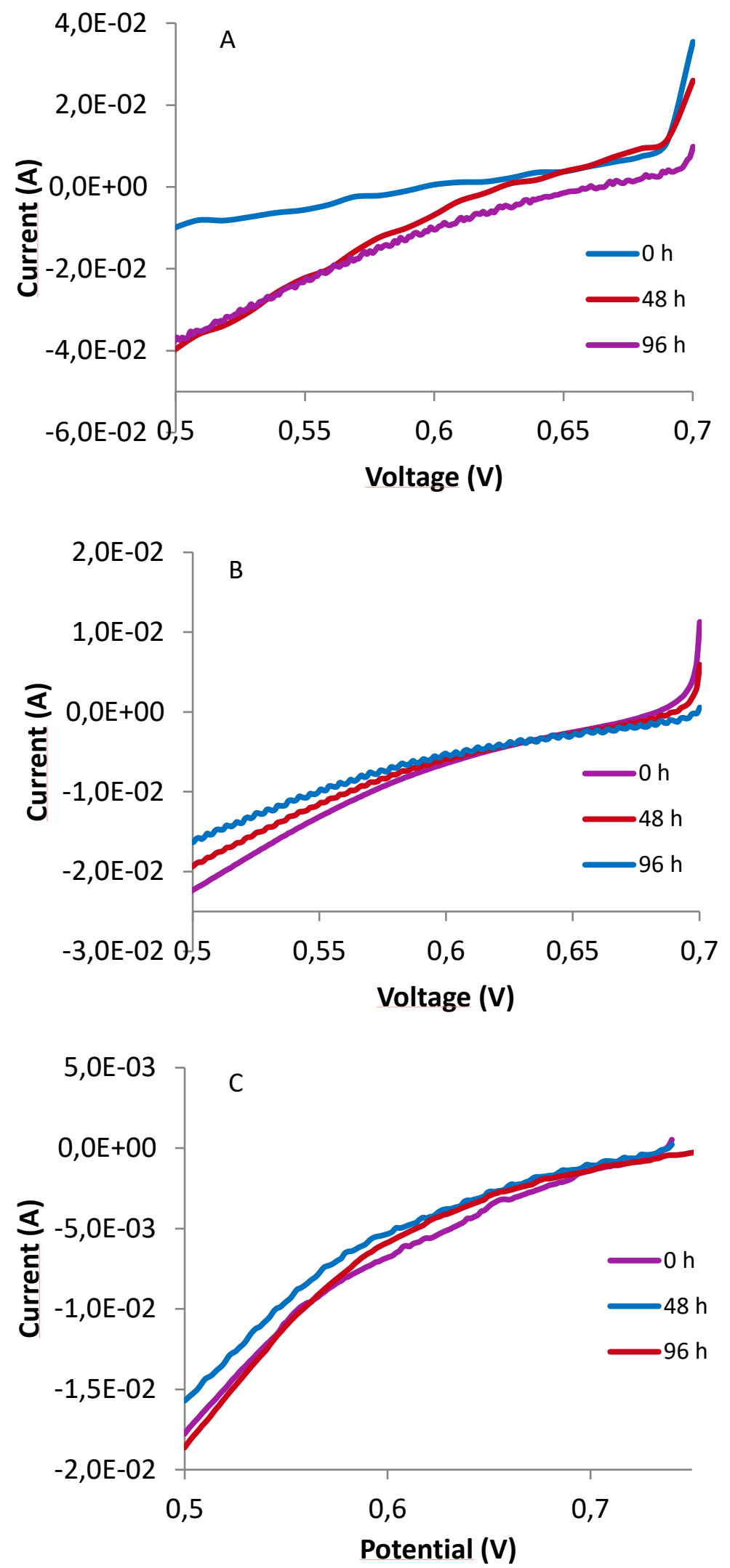

Figure 9. Evolution of the LSV for the different MEAs tested during the lifetest. A) Vulcan XC72; B) SiCTiC; and C) SiC based MEAs 
